\title{
Clinical Legal Education in Malta: Learning from experience and identifying the challenges
}

David E. Zammit (LL.D. Ph.D. Durham University)

Alina Kislova (International Master in Adult Education for Social Change)

\begin{abstract}
This paper introduces the reader to clinical legal education in Malta by: 1) outlining how the internal hybridity of the Maltese legal system and the juxtaposition of English and Continental models in Maltese legal education have influenced the development of the Law Clinic at the University of Malta; 2) describing how the Maltese clinical model operates currently; 3) reviewing the experiences of students involved in clinical work.
\end{abstract}

\section{Delineating the Maltese Legal System}

Situated some $81 \mathrm{~km}$ south of Sicily and nearly $300 \mathrm{~km}$ to the north of Libya in the middle of the Mediterranean sea and with a population of less than 500,000 individuals concentrated in a geographical area of a little over 300 square km, the Republic of Malta is nevertheless a selfgoverning state with its own distinct legal system and University and is simultaneously a member of the European Union and the British Commonwealth. Its legal system is technically considered as a mixed legal system; reflecting its long colonial history; in which the Maltese archipelago was governed for close to three hundred years by the Hospitaller Knights of Saint 


\section{Special Issue: European Network for Clinical Legal Education $6^{\text {th }}$ Conference}

John and subsequently came into the hands of the British; who governed it between 1800 and 1964 (Donlan S. P., Ando' B., Zammit D. 2012, pp.181-191).

The Maltese legal system bears the traces of its colonial past in various ways; not least in the way its Constitution conforms to the Westminster model and in the persistence of a narrow positivist way of interpreting human rights legislation which tends to avoid invoking human dignity as an underlying free-standing value (Zammit, D. \& Muscat M. 2019, pp.25-29) The language of the laws is English and Maltese; while court practice and judgments are written almost exclusively in a dialect of Maltese which relies heavily on Italian terminology; testifying to the reliance upon Italian as the official language of the Maltese courts and legislation until the mid-1930's. British colonial rule also introduced a break with the Civilian legal tradition insofar as public law in general is concerned and Maltese public law is now anchored within the British Common law; whereas private law continues to be anchored in the Civilian tradition; particularly due to the existence of five codifications, dating back to the colonial period: the Maltese Civil Code, Criminal Code, Commercial Code, Code of Organisation and Civil Procedure and the Code of Criminal Procedure (Andò, Aquilina, Scerri-Diacono \& Zammit, 2012, p.532). This notwithstanding, Malta's entry into the EU in 2004 and its development of a large financial services industry, e-gaming and ship registration facilities have further reinforced the Common law influence and commercial and I.T. law is heavily reliant upon Common law sources.

The Maltese legal system is thus characterized by a high degree of internal hybridity; expressed very clearly in an overarching division between private law; primarily based upon the Civilian 


\section{Special Issue: European Network for Clinical Legal Education $6^{\text {th }}$ Conference}

legal tradition and a public law which reflects Common law. Unlike other small jurisdictions, the level of mixing within the Maltese system is so high that it is impossible to identify a single ‘Big Brother' jurisdiction; with a hegemonic role in shaping Maltese law. Indeed:

“An inclination towards one or another external cultural and legal influences-Britain or Italian - has a long genealogy in the context of Maltese state building." (Donlan S. P., Marrani D., Twomey M. \& Zammit D.E., 2017, p.193)

Ultimately it was only EU membership which helped the Maltese population and its legal class come to terms with and accept the various cultural and legal influences which have shaped its legal system:

“This was achieved in 2004. Membership is seen, consistent with this history, as compatible with the exercise of Maltese sovereignty. Moreover, EU membership reconciled the various loyalties-British, Italian, and Maltese-adhered to in Malta. As a result, it was possible to be all three at once." (Donlan S. P., Marrani D., Twomey M. \& Zammit D.E., 2017, p.194)

The way in which Maltese jurists have responded to these various influences has been by developing a view of the legal system as: "composed of a number of clearly distinguished compartments" (Ganado, J. 1996, p. 247). This approach is combined with a "pragmatic purism" (Andò, Aquilina, Scerri-Diacono \& Zammit, 2012, p.563-568) on their part; which while accepting a high degree of mixing at the level of the system as a whole; nevertheless insists that within each compartment there must be cultural consistency between sources and interpretation. 


\section{Special Issue: European Network for Clinical Legal Education $6^{\text {th }}$ Conference}

\section{Situating the Law Clinic within Maltese Legal Education}

In Malta, legal education has long represented a compromise between the English model which envisages a process where the undergraduate study of law at University is followed by professional legal study at one of the Inns of Court- and the Continental model; which traditionally envisages the postgraduate study of law at University as the next step in the formation of an advocate following undergraduate study. Until the early 1990's, the LL.D. degree -awarded after 6 years of undergraduate study at the University of Malta and incorporating the completion of a final dissertation- was the primary requirement which needed to be satisfied in order to be granted the warrant allowing its holder to practice the profession of advocate in Malta. A pass in the warrant exam organized by the State following a year of professional apprenticeship after graduating was the secondary prerequisite. While this might appear to come close to the Continental law model, in practice it diverges significantly from it because: (1) English is the language of University teaching of law, meaning that English language texts are becoming the primary medium through which important legal concepts are transmitted, (2) doctrinal texts on Maltese law are few and often outdated; meaning that the study of court judgments written in the Maltese language often takes the place of a more purely scholarly study of academic texts (Donlan S. P., Ando' B., Zammit D., pp.194-195), (3) Maltese law-teaching was until recently almost completely dominated by parttimers, who are practicing advocates and who tend to present the process of 'becoming' a lawyer as: 


\section{Special Issue: European Network for Clinical Legal Education $6^{\text {th }}$ Conference}

"consisting of two phases. In the first six years, the University degree is obtained. In the following two to three year period of 'prattika' (i.e. practice) a law graduate attaches himself to an established lawyer as a glorified office-boy. In return for helping with the more mundane tasks of lawyering, he gains the opportunity to observe his lawyer-patron advising clients, drafting judicial acts and engaging in litigation in court. A rigid demarcation is maintained between the two phases and only those law graduates who undergo the second phase begin to earn the right to be considered as 'real' lawyers by members of the profession. Law students are constantly told that 'il-prattika kollox' (legal practice is what counts), and that: 'meta tohrog mil-universita tkun ghadek ma taf xejn' (when you emerge from University, you as yet know nothing)" (Zammit, D. 1993, pp.60$61)$.

The dominance of practitioners in Maltese law-teaching thus combines with the tendency to view the jurisdiction in compartmentalized terms; resulting in a rigid opposition between 'theory' and 'practice'; in which the former is devalued, while the latter is valorized. This compartmentalized approach is also reflected in the syllabus, with subjects like Civil law taught primarily through the medium of Maltese jurisprudence and Italian textbooks, side by side with subjects like Constitutional law, taught primarily through English language books. The dominance of practitioners in law teaching, the lack of a single dominant 'Big Brother' jurisdiction and the broad and eclectic variety of foreign sources which are tapped in the process of constructing the syllabus for Maltese legal education also means that: 


\section{Special Issue: European Network for Clinical Legal Education $6^{\text {th }}$ Conference}

"educators do not perceive legal education as the wholesale adoption of a particular pedagogical model rooted in a homogenous understanding of law characterising a single dominant (external) legal tradition. Instead, they understand Maltese legal education as the elaboration of an indigenous model through selective borrowing from various sources, feeling empowered to draw selectively on foreign models." (Donlan S. P., Marrani D., Twomey M. \& Zammit D.E., 2017, p.196)

\section{Developing the Maltese law clinic}

The Maltese law clinic developed in a way which adapted and tried to respond to the above noted characteristics of Maltese legal education. The initial impetus for institutional change in law teaching came about as a result of increased pressure from University authorities to rationalize the structure of the law course. This pressure was itself partly justified in terms of the need to align legal education with the Bologna process; by ensuring that the undergraduate teaching of law would not take more than three or four years and that the overall duration of the course would not extend beyond five years in all. At the same time, the creative syncretic response of the Law Faculty reveals that they saw themselves as "actors of legal globalization and not its victims." (Donlan S. P., Marrani D., Twomey M. \& Zammit D.E., 2017, p.196)

From the 2017/18 academic year onwards, the overall duration of law studies was reduced to five years; consisting of a four-year long undergraduate LL.B. degree meant to cover all the substantive law that a 'general practitioner' advocate needs to know followed by a one-year long Masters course in Advocacy. The Masters in Advocacy was initially envisaged as a course 


\section{Special Issue: European Network for Clinical Legal Education $6^{\text {th }}$ Conference}

which combines the academic teaching of procedural law and other practice-related academic subjects, with a new 30-credit study unit called 'Professional Practice' and consisting of lectures in Advocacy Skills, Professional Ethics and related practical skills; together with role plays and simulations of client interviews, moot courts and other real practical scenarios. However, as from the 2018/19 academic year, all law students were also expected to assist real clients by means of supervised pro bono work in the framework of 'The Law Clinic'. This institution had been formally set up around three years previously by means of a memorandum signed by the Rector of the University, the President of the Chamber of Advocates (the Maltese Bar Association) and is hosted by the Cottonera Resource Centre; a branch of the University which seeks to bring it closer to people of the Cottonera region; a region characterized by relative socio-economic deprivation compared to other parts of Malta.

Through the development of the postgraduate Masters in Advocacy course, Maltese legal education continued to reflect Continental trends since students are required to study law at both undergraduate and postgraduate levels in order to qualify academically to practice as advocates. At the same time, by inserting the mandatory requirement that all law students undertake supervised law practice in the context of the law clinic as an integral part of this Masters, the course as a whole was also brought closer to English legal education inasmuch as the requirement of an additional period of professional legal study was also integrated within the University postgraduate course itself.

Key characteristics of the Maltese clinical model must also be understood as an adaptive response to the specific challenges presented by Maltese legal education. In particular the 


\section{Special Issue: European Network for Clinical Legal Education $6^{\text {th }}$ Conference}

categorical division between theory and practice poses particular problems to the law clinic, which attempts to link theory and practice together in a mutually beneficial way.

\section{The Maltese Clinical Model}

The Law Clinic at the University of Malta is a free, student-led legal service in Malta, which started to operate in 2007. As its name implies, from a pedagogical perspective, the Law Clinic falls under the broad umbrella of the Faculty of Laws at the University of Malta (further- UoM) based at the Cottenera Resource Center.

The Clinic has two main objectives: it serves as a channel through which marginalized categories may obtain access to justice, learn about their rights and seek remedies to rectify the injustices that they suffer from. And since the main providers of free legal service to the vulnerable population are students, the Clinic also serves as a learning platform raising professionals that are more socially-conscious and socially - oriented. By making the knowledge and expertise available pro bono to people whose access to justice is limited, Law Clinic places students, who are pursuing a law degree, in touch with the central meaning of the legal profession which is the vocation to pursue justice through law.

The Law Clinic at the UoM is a part of global movement, which responds to the need for incorporating experiential and transformative learning into legal education in the higher education setting. It embodies the practical dimension of the legal course that helps the students to perceive the law differently by working on real cases under the supervision of qualified practicing advocates - the members of the Chamber of Advocates. 


\section{Special Issue: European Network for Clinical Legal Education $6^{\text {th }}$ Conference}

From the standpoint of its academic structure, the Law Clinic operates within the Advocacy Skills component of the Professional Practice Course, which aims to train students in using the skills and methods required in order to assist clients; particularly through helping them prepare and present a legal case. Structurally the course also includes lectures on client interviewing, case planning, fact investigation, case theory, witness examination and writing a legal brief. The final grade is based partly on oral and written exercises carried out in the classroom context (including a first client interview role play and a moot court) and partly on a portfolio prepared and defended by each student-team of two students; documenting their performance in the course of the practical pro bono work performed in relation to a client.

Each student team is allocated a practical supervisor, who must be a warranted practicing advocate and who takes legal responsibility for all decisions taken in the case and students are advised that they must consult with their supervisor and obtain his or her authorization before taking any practical steps in relation to their clients. Furthermore, each student team is given academic supervision by means of supervised case rounds, coupled with lectures focusing on the practical skills students need to deploy in order to adequately assist their clients. This academic supervision is provided to small groups of up to 20 students in the context of the University by academics who are also warranted advocates. Thus this system of dual supervision is intended to overcome the theory-practice dichotomy by encouraging student teams to take initiatives on the assumption that the client's case depends on them; while ensuring that legal responsibility is carried by a practicing advocate. 


\section{Special Issue: European Network for Clinical Legal Education $6^{\text {th }}$ Conference}

The operational side of the Law Clinic is the following: a potential client calls to the Cottenera Resource Center (further - CRC) and talks to its administrator about an existing legal problem. CRC's administrator calls to Dr Kurt Xerri who is a manager of the Law Clinic and together with Dr David E. Zammit will allocate a student team to every existing case, taking into account the type of dispute and students' interests stated beforehand. The student team will meet the client for a first interview, which is solely dedicated to information gathering and developing a relationship with the client. Then the student team sends Dr Xerri the minutes of their meeting and on the basis of those minutes Dr Zammit and Dr Xerri will allocate a practical supervisor to the team.

The relationship between students, clients and supervisors is structured in such a way that mostly it is the duty and responsibility of the students to keep direct contact with clients. Practical supervisors will only intervene in the student-client relationship if there is a real need for it. However, students are supposed to meet their practical supervisors ideally once a week to ask questions they are interested in and to receive necessary recommendations. In addition, it is important to note that students lead the cases only to the certain point (in most cases without leading them to the court) and then they refer the case to three possible instances: an NGO working on the issues concerning the type of a dispute, the legal aid lawyers, or a private lawyer contacted by the client. 


\section{Special Issue: European Network for Clinical Legal Education $6^{\text {th }}$ Conference}

\section{Reviewing the experiences of students}

Over the years that the Clinic has existed, no one has yet investigated the UoM Law Clinic's impact on students' personal and professional skills, attitudes, beliefs. Therefore, in May 2017, it was decided to conduct an evaluation process by means of a small-scale research on this matter. The main aim of the evaluation process was to reveal the impact students' involvement in the Law Clinic work had on their personal and professional development. Due to the fact that the evaluation process was conducted through a small-scale research that requires to be correlated with the literature on the relevant topic, the aim of the research was much broader than just impact evaluation. The overall aim of the research was to explore to what extent transformative and experiential learning is happening through clinical legal education in Malta.

\section{Methodology}

According to Leedy and Ormrod (2005), methodology "dictates the particular tools the researcher selects" (p. 12). In order to choose the most appropriate tools to be adopted, it is necessary to look at the nature of the research aim and questions.

Our study aimed to explore transformative and experiential learning in clinical legal education in Malta while studying the perspectives of students who experience these learning types. Geertz (1973) stated that topics such "as how people are experiencing an event, a series of events, and/or a condition" (p.6) indicate that a qualitative study should be employed. This, in turn, implies the use of qualitative methods and tools (Morrow, 2005). 


\section{Special Issue: European Network for Clinical Legal Education $6^{\text {th }}$ Conference}

A questionnaire consisting of a set of open-ended questions was selected as the most appropriate tool to tackle the research question and to achieve the research aim, because openended questions are asked to give participants more options for responding (Creswell, 2012). Moreover, taking into account a relatively large population size, a mailed questionnaire was used to enhance the feasibility of the research design by collecting data in the relatively quick and inexpensive manner that according to Bell (1999) this questionnaire distribution type is appropriate for. Moreover, as suggested by Creswell, (2012) to encourage a high response rate it was also decided to employ a three-step procedure, by including "a follow-up procedure" within the data collection stage (p. 391). In order to have more uniform and accurate data, students' replies were obtained anonymously; which according to Seligerand \& Shohamy (2000) encourages respondents to be honest.

The questionnaire that was used as a data collection instrument for this study is presented below (see Appendix).

\section{Recruitment and profile of participants}

All prospective participants were involved (in their past or present time) in the Law Clinic activities that serve as the main platform where students obtain hands-on experience while studying law at the University of Malta. In order to recruit students to participate in the research, email addresses were obtained with the assistance of the Clinic's administration staff. Then students were directly contacted by a researcher through emails with an offer to take part 


\section{Special Issue: European Network for Clinical Legal Education $6^{\text {th }}$ Conference}

in the research. From 20 randomly invited students, eight students responded positively to the invitation.

Thus, below there is the analysis of the data obtained from eight students (two current and six former students), who participated in a small scale research aiming to explore to what extent transformative and experiential learning is happening through clinical legal education in Malta while evaluating the impact students' involvement in the Law Clinic work had on students' personal and professional development.

\section{Data analysis}

In order to achieve the aims of the evaluation process and the study, within which this process is employed, the data obtained from questionnaires was analysed using the following steps: coding and memorizing, identification of themes and categories, displaying and reporting, and concluding the results (Lichtman, 2013; Punch \& Oancea, 2014). Thematic analysis was chosen as the most beneficial type of analysis due to two main reasons. Being free from its theoretical framework, the thematic analysis gives the researcher an opportunity for a flexible data analysis that has the power to provide a detailed and complex account of data (Braun \& Clarke, 2006). Secondly, it provides a systematic approach for identifying and analysing recurring patterns across the dataset thanks to that major themes and sub-themes are getting formed (Braun \& Clarke, 2006). The data were analysed inductively to assure the validity of the research findings (Cohen et al., 2018). The codes from students' questionnaires data were gathered into categories and crosschecked with previously-defined topics. As a result, the 


\section{Special Issue: European Network for Clinical Legal Education $6^{\text {th }}$ Conference}

categories were clustered into two major themes with various sub-themes: (1) students' perception of the Clinic and/or learning that takes place there; (2) the impact of the students' involvement in the Law Clinic work.

Research findings and discussion

\section{Students' perception of the Clinic and/or learning that takes place there.}

Although there were no direct questions in the data collection instrument that aimed at finding how students perceive learning obtained in the clinic, during the data analysis process information relevant to this issue was nevertheless revealed. As a result, primary data containing some information on this matter was after the analysis structured into two subthemes.

1.1. The Clinic served as a continuation of the learning obtained in the classroom and helped to put theory into practice.

Four out of eight students declared that they found experiential learning and the information received in the Clinic as a continuation of their classroom learning. It was stated by the students as part of their answer to the question about potential differences students perceive between the nature and an application of law in the framework of Law Clinic and in the classroom environment. Below there are statements made by two different students which most effectively communicated this idea: 


\section{Special Issue: European Network for Clinical Legal Education $6^{\text {th }}$ Conference}

"Most of the time I was able to fully rely on my lecture notes when handling the various clients that we had, so the lecturers do explain the law in a way that allows us to easily apply it";

"Experiences like this help balance the huge academic materials we must study and the more crude methodology we must use, as academic learning and practice are in no way mutually exclusive but in actual fact very complimentary".

These ideas are highly connected with the students' perceptions of the Clinic as the one that helped them to put theory into practice. Taking into account that students first learned legal theory in the classroom setting and later on, applied it within the clinical setting, it portrays the Clinic as the extension of the learning students acquired in the classroom. There are two students' excerpts below that directly refer to this:

"The clinic bridges the theory to the practice";

"The law clinic gave me an opportunity to put theory to practice".

This is in direct correlation with the mechanism of the experiential leaning cycle that as Kolb and Lewis (1986) state, makes abstract concepts 'real' as the learner can see examples and applications of concepts occurring in their experience (p. 100).

Moreover, "to test legal theories in practice" is the opportunity presented by Romano et al. (2017) that the clinical form of legal education is intended to provide (p. 277), that is, in its turn, a means to experience abstract legal learning content (Burke, 2007).

1.2. The Clinic's staff was supportive, helpful and provided enough guidelines. 


\section{Special Issue: European Network for Clinical Legal Education $6^{\text {th }}$ Conference}

In response to the direct question about the information and/ or assistance from the staff of the Law Clinic that students were provided with, all students reported that during their involvement in the clinical work they received quite a sufficient amount of support and assistance from the Clinic's staff. The following words came from students:

"Our supervisor has all the necessary expertise and offered all the help we needed in preparation, during and after the interviews";

"Supervisors were always available to guide us and give constructive criticism".

The characteristics of the Law Clinic's staff and its assistance reported by students are similar to the characteristics the transformative learning facilitator is required to have. Taylor (1998) states that being "trusting, empathetic, caring, authentic, sincere, and demonstrating a high degree of integrity" (as cited in Guthrie, 2004, p. 412) are the characteristics a transformative learning facilitator is supposed to possess and that contribute into the creation of safe and supportive learning space.

2. The impact of the students' involvement in the Law Clinic work.

Due to the fact that the main aim of this evaluation process was to explore the impact students' involvement in the Law Clinic work had on their personal and professional attitudes, belief and skills, at the data collection stage the greatest attention was given to reveal this impact. As a result, primary data consisted of the rich information on this matter; that after the analysis was structured in four sub-themes. 


\section{Special Issue: European Network for Clinical Legal Education $6^{\text {th }}$ Conference}

\subsection{The Clinic developed certain student's skills (professional /general).}

The study helped to reveal a list of new skills students developed while being involved in Law Clinic's work. It was decided to split them into two groups: professional skills and general skills. Among the skills that might be useful for a lawyer and that students perceived as being developed through the Clinic, the greatest attention was given to interviewing skills. Five out of eight students mentioned in their replies this type of new skills acquired and developed through the Clinic:

"It was useful in developing client interviewing skills";

"Learned interviewing skills".

In relation to general skills and abilities, two students pointed out the increased level of selfconfidence:

"Helped me to come out of my introverted shell and to speak easily with clients";

"Clinic helped me to gain a certain amount of confidence".

Kolb (1986) and Burke (2007) suggest that a significant learning outcome of the hands-on experience obtained at the university clinics is the increase in students' self-confidence. Improvements of communication skills are considered by students and legal educators as one of the reasons for gaining self-confidence (Turner et al., 2016). In this regard, our findings not only show that both students' capacities were developed as a result of the hands-on experience 


\section{Special Issue: European Network for Clinical Legal Education $6^{\text {th }}$ Conference}

obtained at the Clinic but also prove that a direct correlation indeed exists between gaining self-confidence and improvements in communication skills.

Since, according to Virgil (2016), only work-based learning is capable to build students' professional technical skills, it would not be possible to develop the ability not to be under stress while interviewing a client and to ask an appropriate set of questions if students were not exposed to the real work setting.

Moreover, there are some other significant inputs different students mentioned as being produced by the Clinic:

"Helped me to make professional contacts";

"Raised an understanding that it is important not to stereotype".

The last student's statement is in line with Burke's (2007) idea that work-based learning enhances critical thinking of students. This may be attributed to the way work-based learning allows students to encounter broader social issues that at the same time definitely contribute towards broadening student's sources of information and social networks (Virgil, 2016).

\subsection{The Clinic expanded the students' understanding of law (legal complexity).}

The overwhelming majority of the students confirmed that their experiences in the Law Clinic expanded their understanding of law. Once they got the chance to participate in a real legal process, they realised that law is broader, more complex and much more versatile than they 


\section{Special Issue: European Network for Clinical Legal Education $6^{\text {th }}$ Conference}

originally anticipated. There are two students' statements below representing this finding most clearly:

"In the classroom, things are usually pretty straightforward and the scenarios are black or white. In real life, things become more diverse and broad";

"We learned the utopian perspective of law in class, cause while working with the client we realised that many of the principles we learned about are ignored in practice".

The changes described in students' understanding of the subject studied are in line with the impact experiential learning usually has on the way students learn particular subjects. Turner, et al. (2016) state that, due to the opportunity to test legal theories in practice provided by experiential learning, students experience legal complexity and understand the law better. The words students used to characterise the changes that occurred in their understanding of law are diverse, such as 'more diverse and broad', or 'more complex', but all of them highlight the legal complexity experienced by the students. An overall enhancement of students' understanding of course content is, as Burke (2007) states, also one of the learning outcomes of the experiential learning approach employed in the academic environment.

2.3. The Clinic helped students to see a social justice dimension to law and to the legal profession.

Six out of eight students who participated in the evaluation process of their clinical experience attested that it helped them to see a different role of law and of a legal professional; that is a social justice role. Despite the fact that every student expressed this idea by describing a 


\section{Special Issue: European Network for Clinical Legal Education $6^{\text {th }}$ Conference}

different aspect of this social justice process, most of them acknowledged the importance that this aspect of the law and the legal profession be exercised. These are some of the students' statements connected with social justice ideas:

"It gave me a new perspective of how law can be of service to the least advantaged";

"My perception of the legal profession was influenced dramatically as I was exposed to the harsh realities of clients from different social strata. The Legal Clinic was a challenge for us as students to try to bridge that gap and provide help not only as budding lawyers, but as humble young people with a vocation towards Law as a public service";

"I realised that money is not that much important than the happiness felt when helping those in need".

In connection with this, it is worth stating that many academics and practitioners suggest that work-based learning, being a part of the academic program curriculum, goes further than just enhancing students' skills and knowledge (Santalucia \& Johnson, 2010). The words of Mezirow (1991) can serve as evidence that, " ...the workplace is an ideal environment which can provide cognitive tools (e.g. theories, ideas, practices, concepts) to enable students to not only gain knowledge and skills but also shape their ideas, perspectives and meanings" (as cited in Babacan \& Babacan, 2015, p.173). The lack of opportunity to be engaged in the work-based learning "limits an understanding of the social context in which the special discipline operates" (Babacan \& Babacan, 2015). According to Freire (1970, as cited in Babacan \& Babacan, 2015, p. 172), preventing students from being attributed civic responsibility during the educational 


\section{Special Issue: European Network for Clinical Legal Education $6^{\text {th }}$ Conference}

process, prevents them from becoming active society members. So-called "engaged citizenship" can be promoted only through the clinic's or field placement's activities. (Burke, 2007, p. 8).

2.4. The Clinic helped students to realise the importance of other needs (non-legal advisory) clients might also have.

The vast majority of students reported on the importance of other needs (not legal advisory) that clients have, while coming to a lawyer for a legal help. Among these students mentioned various needs, and some of them are presented below:

"Most importantly it helped me realise that our role as legal professionals sometimes entails going beyond the purely legal and actually acknowledging and validating people's emotions";

"Clients might also need other things: to listen and guide them";

"I also learned it is also important to client that they have someone to listen to them, and that many times that matters to them as much as winning the case";

"Helped me understand that a lawyer can make a real difference to a client, not just with their legal knowledge and skills, but also, and in equal measure, with their compassion and willingness to listen".

Pointing out different aspects, every student acknowledged to a certain degree that working in the Clinic, while helping them to realise the things described above, transformed the initial belief they possessed in the importance of a particular legal need clients have, as this was 


\section{Special Issue: European Network for Clinical Legal Education $6^{\text {th }}$ Conference}

proved (by their clinical work) not to be true. One of the main work-based learning outcomes is the change in attitudes, beliefs and values occurring in a student's mind after he or she "encounters a perspective that is at odds with his or her current perspective" (Kroth \& Cranton, 2014, p.3). The terms 'attitudes, beliefs and values', as Mezirow (2000, as cited in Santalucia and Johnson, 2010, p.2) states, are united by one definition, "a frame of reference". This, following the transformative learning approach, is to be challenged by theories of practice (Guthrie, 2010).

\section{Conclusions}

In conclusion, this study demonstrates the active use of transformative and experiential learning and its particular elements within the Law Clinic at the University of Malta. The findings drawn from the modest data obtained from eight students, serve as a source of information on the mostly positive students' perceptions of the learning happening in the Law Clinic and the positive impacts it brings. The Clinic, while serving as a continuation of the learning obtained in the classroom, helped students to put theory into practice; bridging the theory/practice divide which is problematic in Malta. The Clinic's staff played a positive role in the learning process by being supportive and helpful and by providing enough guidelines to students, that, according to Mezirow (2003, as cited in Babacan \& Babacan, 2015, p. 172), are "necessary prerequisites for a deep transformation of personal values, attitudes and beliefs".

The involvement in the Law Clinic work had various positive impacts on students, that are in line with the transformative and experiential learning objectives, as such reinforced students' 


\section{Special Issue: European Network for Clinical Legal Education $6^{\text {th }}$ Conference}

understanding of a study subject (that is the law); changed beliefs; developed certain student's skills and promoted "engaged citizenship".

\section{Limitations}

There exist a number of limitations to the evaluation conducted through this study. The research was conducted on a small scale due to limited time allocated to it and this restricts the findings' depth. The study provides information on students' learning experiences obtained within the University of Malta Law Clinic and various impacts they had on students. However, as the research focuses on a very small sample, more comprehensive data could be gathered by distributing more questionnaires among students. Analysis of secondary data such as empirical and conceptual papers in clinical legal education field that present various critical perspectives on transformative and experiential learning should also be taken into account.

\section{References}

Andò, B., Aquilina, K., Scerri-Diacono, J. \& Zammit, D. (2012) Malta. In V. Palmer (Ed.) Mixed Jurisdictions Worldwide: The Third Legal Family (2nd Ed.). Cambridge University Press, Cambridge, p 528-576 
Special Issue: European Network for Clinical Legal Education $6^{\text {th }}$ Conference

Babacan, A., \& Babacan. H. (2015). A transformative approach to work integrated learning in legal education. Education + Training, 57(2), 170-183. Retrieved from https://doi.org/10.1108/ET-07-2013-0098

Bell, J. (1999). Doing your research project: A guide for first-time researchers in education and social science. Buckingham, England: Open University Press

Burke, D. (2007). Service learning: opportunities for legal studies in business. Journal of Legal Studies Education, 24(2), 129-163. Retrieved from https://doiorg.ejournals.um.edu.mt/10.1111/j.1744-1722.2007.00037.x

Cohen, L., Manion L., \& Morrison, K. (2018). Research Methods in Education (7th Ed.). Routledge.

Creswell, J. (2012). Educational Research: planning, conducting, and evaluating quantitative and qualitative research ( $4^{\text {th }}$ Ed.). University of Nebraska. Lincoln: Pearson

Donlan, S., Andò, B. \& Zammit D. (2012) “A happy union?” Malta's legal hybridity. Tulane European and Civil Law Forum 27:165-208

Donlan, S., Marrani, D., Twomey, M. \& Zammit, D.E. (2017) Legal Education and the Profession in Three Mixed/Micro Jurisdictions: Malta, Jersey and Seychelles. In P. Butler, C. Morris (Eds.) Small States in a Legal World. Cham, Switzerland: Springer International Publishing, p 191-212

Ganado, J. (1996) Malta: A Microcosm of International Influences. In E. Örücü, E. 
Special Issue: European Network for Clinical Legal Education $6^{\text {th }}$ Conference

Attwooll, S. Coyle (Eds.) Studies in Legal Systems: Mixed and Mixing. The Netherlands: Kluwer Law International, p 225-247

Geertz, C. (1973). The interpretation of cultures: Selected essays. New York: Basic Books.

Guthrie, B. (2004). Facilitating a transformative learning environment: a case study of its use in a graduate level psychology course. In K. D. Kirstein, J. M. Hinrichs, \& Steven G. Olswang (Eds.), Authentic instruction and online delivery: proven practices in higher education (pp. 391-419). Retrieved from: https://repository.cityu.edu/bitstream/handle/20.500.11803/527/Chapter26Aut hentic.pdf?sequence $=2 \&$ isAllowed $=y$

Kolb, D., \& Lewis, L. (1986). Facilitating experiential learning: observations and reflections. New Directions for Adult and Continuing Education, 30, 99-107.

Kroth, M., \& Cranton, P. (2014). Stories of transformative learning. Rotterdam: Sense Publishers.

Leedy, P.D., \& Ormrod, J.E. (2005). Practical research: planning and design. Upper Saddle River, NJ: Prentice Hall.

Lichtman, M. (2013). Qualitative research in education: a user's guide (3 ${ }^{\text {rd }}$ ed.) SAGE Publications, Inc.

Morrow, S.L. (2005). Quality and trustworthiness in qualitative research in counselling psychology. Journal of Counselling Psychology, 52(2), 250-260. doi: 10.1037/00220167.52.2.250 
Romano, A., Hirsch, S., \& Paczynska, A. (2017). Teaching about global complexity: experiential conflict resolution pedagogy in higher education classrooms. Conflict Resolution Quarterly, 34(3), 255-279.

Santalucia, S., \& Johnson, C. (2010). Transformative learning: facilitating growth and change through fieldwork. OT Practice, 15(19), CE1-CE8.

Seliger, H., \& Shohamy, E. (2000). Second language research methods. Oxford University Press

The University of Malta. (2019). Study-Unit Description. Retrieved from: http://www.um.edu.mt/laws/studyunit/LAW5005

Turner, J., Bone, A., \& Ashton, J. (2016). Reasons why law students should have access to learning law through a skills-based approach. The Law Teacher, 52(1), 1-16. doi: $10.1080 / 03069400.2016 .1201739$

Virgil, S.M. (2016). The role of experiential learning on a law student's sense of professional identity. Wake Forest Law Review, 51(2), 325.

Zammit, D., (1998) Laws and stories: an ethnographic study of Maltese legal representation. Doctoral thesis, Durham University. Retrieved from http://etheses.dur.ac.uk/5050/?fbclid=IwAR3n7oxFXxfPJb0Jv9Tr_YDE6iWk yavceK8Qg-xf6VlavJl_fI4q6V4HPqs

Zammit, D., \& Muscat M. (2019) Human Dignity in Malta. In P. Becchi, K. Mathis (Eds.) Handbook of Human Dignity in Europe. Switzerland: Springer Nature, pp.1-32 
Special Issue: European Network for Clinical Legal Education $6^{\text {th }}$ Conference

Appendix A

Questionnaire for the University of Malta Law Clinic Students

Many thanks for your participation. Your answers will be used anonymously.

1. Are you a former or current student involved in Clinic's practice?

2. How long have you been participating as a student in the Law Clinic's activities?

\begin{tabular}{|l|l|l|}
\hline Less than & 1 semester- 1 & 1 or more years \\
1 semester & year & \\
\hline & & \\
\hline
\end{tabular}

3. Please state whether your experience in the Law Clinic has influenced your perception of a legal profession.

4. Please state whether your experience in the Law Clinic has influenced your personal development.

5. Please state whether your experience in the Law Clinic has influenced your legal career. 


\section{Special Issue: European Network for Clinical Legal Education $6^{\text {th }}$ Conference}

6. Have you noticed any difference between the nature and an application of law in the framework of Law Clinic and the same issues explored in the classroom environment? Please provide reasons for your answer.

7. How can you assess the level of help which was provided to you by supervisors or any other administrative staff during your involvement in the Law Clinic.

8. What are the most important things you have learned or skills you have developed while participating in the Law Clinic's activities as a student?

9. While participating in the Law Clinic's activities you have interacted with the Maltese justice system directly or indirectly. Please describe how this system (especially the Chamber of Advocacy, Ombudsmen, Courts) affects implementation of work you proceed and provide any ideas for improvement. 